\title{
MEMÓRIAS DE FORMAÇÃO: sentidos e sensibilidades durante o início da vida religiosa na Congregação das Irmãzinhas da Imaculada Conceição (1960 - 1990)
}

\author{
Caroline Jaques Cubas*
}

\section{Resumo}

O objetivo deste artigo é discutir diferentes aspectos da formação religiosa feminina sob a ótica da sensibilidade e do disciplinamento. Para tanto, apresentamos testemunhos de mulheres que passaram pelo processo de formação na Congregação das Irmãzinhas da Imaculada Conceição. Os depoimentos, postos em diálogo com os manuais de formação, constroem um panorama bastante amplo, o qual permite vislumbrar a construção de sentidos e de vocações para o posterior trabalho institucionalmente ligado à Igreja Católica.

Palavras-chave: Vida religiosa. Formação. Disciplina. Memória.

Minhas memórias me levam aquela casa... Azul com uma área cheia de samambaias, um tanque, o chão brilhando, uma TV preto e branco, um sofá vermelho... desenho tudo quando lembro."1

Onice relembra com facilidade e em cores os anos que passou em formação nas casas das Irmãzinhas da Imaculada Conceição, em fins dos anos 80. Segundo lembra, criava-se um forte sentimento de pertencimento uma vez que durante os anos de formação se convivia com o mais profundo de si. Ao falar das irmãzinhas, admite reportar-se em detalhes à casa onde morou, tudo o que fez, tudo que aprendeu, o cheiro das coisas. ${ }^{2}$ Aquilo que marcou e está presente em seu corpo. Os hábitos vividos e incorporados. Tanto que é apossada de extremo

\footnotetext{
* Doutoranda em História pela Universidade Federal de Santa Catarina. Email: caroljcubas@gmail.com

${ }^{1}$ Sansonowicz, Onice. Correspondência enviada à Ir. Eni, em 2005. Acervo da autora.

${ }^{2}$ Entrevista com Onice Sansonowizc realizada em 26 de março de 2006. Acervo da autora.
} 
sentimentalismo ao relembrar os anos de congregação. Ainda hoje afirma a impossibilidade da passagem impune pelo Colégio São José ou pela cidade de Nova Trento (suas referências de congregação em Santa Catarina). ${ }^{3}$

A formação religiosa acontecia (e assim ainda é) em etapas: animação vocacional, aspirantado, postulantado, noviciado, juniorato e formação permanente. Tais etapas possuíam especificidades e não eram fixas. Davam-se em espaços diferenciados, conhecidos como Casas de Formação e representavam um período de aprendizagem intensa. Eram, em média, quatro anos, em que a jovem futura irmãzinha aprendia efetivamente a ser uma religiosa, a viver e a sentir como tal.

Cada uma das etapas acima citadas acontecia em uma casa específica. De acordo com a ir. Maria Cristofolini, a itinerância tem um significado simbólico. As "irmãs não podem criar raiz”, disse-nos ela, ao explicar que cada etapa de formação, assim como a vida religiosa, se dá de forma itinerante por seguirem o ideal da vida de Cristo e de Madre Paulina. Este ideal, cujo objetivo maior é a busca por santidade, implica divulgar o evangelho e estar disponível para atender às necessidades dos outros. ${ }^{4}$

A questão da formação tem sua importância potencializada quando consideramos que é na atuação do corpo sacerdotal que encontramos a base de sustentação simbólica do poder da Igreja. Isto porque são estes que possuem a legitimidade da manipulação dos bens e o monopólio do discurso religioso. Assumem a identidade católica através de atos e ritos de consagração que vão instituí-los como representantes autorizados da instituição e possibilitar que sejam reconhecidos como tais.

O espaço de atuação dos sacerdotes (das irmãs, no caso) vai além de delimitações políticas. Ele é conformado por meio das relações estabelecidas entre as religiosas e os leigos. A formação acontece exatamente na conformação destes espaços simbólicos, numa via de mão dupla, em que as irmãs se dedicam a um trabalho de disseminação da verdade religiosa através dos trabalhos da Congregação e os leigos legitimam e possibilitam sua realização ao assumirem as religiosas como representantes de uma instituição, delegando-lhes poder para tanto.

O número de formandas comportado pela casa variava de acordo com o tamanho e as condições de cada comunidade. Vale lembrar que eram mantidas pelo trabalho das próprias irmãs e que, portanto, na maioria das vezes, elas desempenhavam trabalhos paralelos ao de

\footnotetext{
${ }^{3}$ Idem.

${ }^{4}$ Entrevista realizada com a irmã Maria Cristofolini por Caroline Jaques Cubas. Florianópolis, 7 de fevereiro de 2006. Acervo da autora.
} 
manutenção das casas. Não se indicava, no entanto, um número muito grande de formandas em cada casa, variando geralmente entre duas e seis por comunidade. Era durante o período de formação que, através das aulas, da divisão de tarefas e da distribuição de responsabilidades, a futura irmã seria moldada ao interiorizar um comportamento disciplinado. Segundo Foucault, (1998, p. 126) “esses métodos que permitem o controle minucioso das operações do corpo, que realizam a sujeição constante de suas forças e lhes impõem uma relação de docilidade-utilidade, são o que podemos chamar de “disciplinas”. A palavra disciplina, aliás, é a legenda que referencia a utilidade do silício que pertencera a Madre Paulina, atualmente exposto no Museu da Congregação, em São Paulo. O silício, uma cinta com pequenas tachas, utilizado na altura das coxas, era um instrumento disciplinar, utilizado para a contenção de desejos através do sacrifício corporal. Começou a entrar em desuso a partir da década de 1960, com o Concílio Vaticano II. Ainda que os métodos mortificantes não fossem mais tão recorrentes para o exercício da disciplina, esta nunca deixou de estar presente, figurando como um dos principais componentes da formação e da vida religiosa. Neste sentido, a estrutura da formação é organizada de forma bastante disciplinar, objetivando a “fabricação” de corpos dóceis, submissos à autoridade.

A divisão dos espaços de formação em casas distintas de acordo com a etapa formativa comprova esta assertiva. Em cada etapa, a formanda entrava em contato com os exercícios (corporais e espirituais) específicos para o nível no qual se encontrava e, desta forma, qualificava-se gradativamente para a vida religiosa. Conforme Foucault:

O tema da perfeição, em direção à qual o mestre exemplar conduz, torna-se entre eles o de um aperfeiçoamento autoritário dos alunos pelo professor; os exercícios cada vez mais rigorosos propostos pela vida ascética tornam-se tarefas de complexidade crescente que marcam a aquisição progressiva do saber e do bom comportamento (FOUCAULT, 1988, p. 187).

O tempo de formação apresentava-se como um tempo especializado, durante o qual a formanda era analisada e qualificada de acordo com os requisitos atendidos durante as diferentes fases. A divisão em etapas possibilitava também maior controle e intervenção pontual em relação a cada momento específico. Onice narra que, apesar do controle atento, as possibilidades de ludibriá-lo eram bastante frequentes no cotidiano das casas: “A gente acordava cedo, e odiávamos isso; então a gente trancava o relógio despertador... às vezes. Perdíamos a hora da reza... ah que pena!(Com tom irônico) E todo mundo ia consternado 
trabalhar sem rezar...”. 5 Sendo o tempo um dos elementos-chave do controle disciplinar, trancar o relógio adquiria um significado ímpar, de embate em relação à disciplina e, além disso, de verticalização de relações de poder que eram apresentadas às formandas de forma hierarquizada.

A pele é pergaminho. Segundo Michel de Certeau (1994, p. 221-246), corpos são cotidianamente marcados e transformados em quadros vivos de regras e costumes. No caso da vida religiosa, é especialmente durante o período de formação que tais regras são inscritas no corpo. Neste sentido, as constituições da Congregação acabam por compor o estatuto do que deve ser ensinado e incorporado pelas futuras irmãs.

A necessidade de uma norma que regulasse a vida comum manifestou-se já nas primeiras décadas da Congregação, em fins do século 19, quando o padre jesuíta Marcello Rocchi propôs uma espécie de regra a Amábile (M. Paulina) e Virgínia (M. Matilde), composta de 38 exercícios espirituais que se alternavam entre métodos sobre o discernimento do espírito, sobre escrúpulos e sobre sentir com a Igreja. ${ }^{6}$ Ao todo, a Congregação contou com cinco versões das suas constituições e diretórios; a última, atualizada logo após o Concílio Vaticano II, foi apresentada à Congregação para os Religiosos e Institutos Seculares em 1978 e, finalmente, aprovada por decreto em 1982. As irmãs que vivenciaram a formação religiosa nos período de 1960 a 1990 regeram-se pelo que é apresentado nesta versão.

Segundo a ir. Leodi, a formação era muito personalizada. Cabia à formanda e à mestra decidirem quando ela devia continuar em uma etapa ou seguir adiante. ${ }^{7}$ A afirmação de ir. Leodi tem seu sentido potencializado quando encontramos, nos diretórios da Congregação, o objetivo geral da formação religiosa: “Criar condições para descobrir e assumir o projeto de Deus para si mesma”. ${ }^{8}$ Este projeto de Deus, ou seja, o trabalho a ser assumido pela irmã após a profissão dos votos, estava intimamente ligado às necessidades da Congregação. Submeter a vontade individual às necessidades institucionais é apenas uma das condições apreendidas ao longo do processo e assumidas com os votos religiosos. Existe, no entanto, um longo e complexo percurso que antecede este ritual, que se inicia com a descoberta da vocação.

Vocação, dentro de uma congregação religiosa, é um chamado. Uma disposição que orienta ao exercício de uma atividade. Há, porém, necessidade de se incitar tal disposição e isto se dá pela conhecida animação vocacional, etapa que antecede a formação.

\footnotetext{
${ }^{5}$ SANSONOWICZ, Onice. Op. Cit.

${ }^{6}$ Cf. CONGREGAÇÂO PARA A CAUSA DOS SANTOS. Madre Paulina: Fundadora da Congregação das Irmãzinhas da Imaculada Conceição: Biografia comentada. São Paulo, 1986.

${ }^{7}$ BOLZAN, Ir. Leodi, 38 anos. Depoimento, setembro de 2004, Itajaí. Entrevistadora: Caroline Jaques Cubas. Acervo da Autora.

${ }^{8}$ Diretório da Congregação das Irmãzinhas da Imaculada Conceição, p. 63.
} 
Todas as irmãs são agentes de animação vocacional em potencial; no entanto, algumas são especificamente designadas a atuar nesta área, com o auxílio direto da responsável pela formação em cada província. Além das agentes que atuam diretamente junto às candidatas, conta-se com o incentivo dos párocos de cada região e com os meios de divulgação impressos.

Ir. Maria Cristofollini, natural da cidade de Rodeio - SC - e na CIIC há mais de cinquenta anos, conta que conheceu a congregação em reuniões com outras jovens, encaminhadas pelo pároco local, o qual apresentava as peculiaridades de cada congregação e as possibilidades de nelas ingressar. Vinha de família bastante católica, assim como a ir. Leodi Bolzan. Esta, ao descrever seu encontro com as Irmãzinhas da Imaculada Conceição, narra:

\begin{abstract}
Não pensava muito no vestibular, já pensava num curso que pudesse me dar um trabalho que tivesse afinidade comigo (...). Através do trabalho das irmãs nos clubes vocacionais da comunidade onde eu morava é que despertei para esse tipo de vocação. Freqüentei os clubes vocacionais e ficava inúmeras vezes na casa das Irmãs, morei um ano com as Irmãs perto da casa do meu pai para ver como era (...). Elas trabalhavam no hospital então muitas vezes eu ajudava também para ir aprendendo esse tipo de trabalho que as irmãs fazem, e ajudava na catequese, na liturgia, participava em grupos de jovens, já fui me engajando nisso com as irmãs. Naquela época eu tinha 15 anos e ai foi crescendo a vocação. ${ }^{9}$
\end{abstract}

A vocação para a vida religiosa era muito mais do que despertada. Era ensinada em reuniões e acompanhamento intenso junto às que demonstravam alguma propensão ao trabalho realizado pelas irmãs. Mirian P. Grossi (1989) faz constatação similar em trabalho sobre a vida religiosa feminina nos conventos de Santa Catarina, quando afirma que o celibato feminino é uma opção construída pela própria Igreja como instituição, na tentativa de se reproduzir material e simbolicamente. Ressalta a intensidade do trabalho catequético realizado por padres e freiras, especialmente nas áreas rurais, onde estabelecem laços e relações afetivas. Tanto ir. Maria quanto a ir. Leodi confirmam tal assertiva. Isto nos leva a pensar, ainda de acordo com Grossi, nas vocações como resultado de necessidades materiais e simbólicas, tanto individuais quanto coletivas.

Ir. Eni da Silva, quando adolescente, sonhava em ter filhos. Gostava de trabalhar na igreja, participar de grupo de jovens e um dia, incitada por uma amiga e por um anúncio no jornal paroquial, acabou escrevendo à Congregação a fim de conhecê-la. Trocou

\footnotetext{
${ }^{9}$ BOLZAN, Ir. Leodi. Depoimento. Op.cit.
} 
correspondências com as irmãs durante alguns meses, mas as dificuldades impostas pela família (dificuldades financeiras e desgosto em relação à possibilidade de ingresso em uma congregação) aplacaram seu desejo, retomado anos depois, quando ela e sua irmã saíram de casa para estudar e trabalhar em um ambiente diferente da zona rural onde viviam. A Congregação, para Eni, representava a concretização de sonhos, entre os quais o estudo, o trabalho assistencial e, mais tarde, o continente africano, onde trabalhou alguns anos como missionária. $^{10}$

O desgosto da família em relação à opção de Eni pode ser compreendido em um ambiente de tensão. Tensão entre campos simbólicos. O ingresso de uma filha em uma congregação religiosa estaria configurando uma perda no que se refere ao capital social, pois esta não poderia casar e, portanto, estaria impossibilitada de perpetuar sua linhagem e sua família. Por outro lado, possuir uma filha freira representava um aumento no capital simbólico da família. Especialmente nas comunidades rurais, um filho padre ou filha freira era, certamente, um elemento de prestígio.

Onice Sansonowicz também enfrentou dificuldades para ingressar na Congregação. Dificuldades institucionais. Também apresentava afinidade com o trabalho paroquial, em especial com a catequese e os trabalhos de pastoral da juventude. Sua família era fervorosamente católica e encontrava no padre a figura de um amigo próximo. Pe. Osvaldo, bastante dedicado aos trabalhos de inserção e “de esquerda que ele só”, segundo Onice, foi o responsável por apresentá-la à CIIC. Onice, no entanto, queria ingressar na Congregação, mas em sua cidade ou, ao menos, nas proximidades, em São Pedro do Sul, onde as irmãzinhas desempenhavam apenas o trabalho de inserção e não de formação. A formação, no entanto, deveria ser realizada nas comunidades de Medianeira ou Santa Maria, onde a Congregação tinha colégios. O grande problema para Onice era a distância. Depois de muita do pe. Osvaldo, as irmãs aceitaram oferecer a formação em São Pedro, na inserção mesmo. Outro problema, porém, se configurava. Onice contava com apenas 13 anos, quando nos programas de formação religiosa da CIIC, desde 1976, ${ }^{11}$ constava que era desaconselhável retirar jovens de seus ambientes antes de completarem os 14 anos e que, nesses casos, o acompanhamento deveria ser realizado em casa, através de visitas e correspondências.

"Vocês querem vocações, quando a gente encontra meninas que querem se dedicar, meninas maduras, responsáveis, novas sim, mas que já se dedicam à pastoral há um tempão,

\footnotetext{
${ }^{10}$ SILVA, Ir. Eni da. (1958) Depoimento. Setembro de 20005. Itajaí. Entrevistadoras: Caroline Jaques Cubas e Onice Sansonowicz. Acervo da autora.

${ }^{11}$ Disponível no acervo da CRB-SC. Fundo “Grupo de reflexão em Formação”.
} 
ficam colocando empecilhos!” Foram as palavras inconformadas de pe. Osvaldo, segundo o que foi contado para Onice, utilizadas para persuadir as irmãs a abrirem uma exceção. De fato, dias depois, a casa de Onice recebeu a visita de algumas irmãs dispostas a aceitá-la na formação.

Segundo Grossi (1989, pag. 31), as vocações religiosas são “construídas socialmente pelos representantes institucionais da Igreja aliados as condições reais das famílias e das comunidades”. A vocação, dessa forma, é incitada por um conjunto de fatores que não necessariamente precisam ser religiosos ou metafísicos. Dizem respeito a condições sociais, laços afetivos e a projetos pessoais e/ou institucionais.

Outra exigência para o ingresso na congregação, além da idade, era o enxoval. Para as famílias mais humildes, como a de ir. Eni, este se configurava como um verdadeiro problema. Conta:

Só que ela disse, ela me deu uma lista, que eu deveria comprar um enxoval. Tinha que ter o enxoval, trazer lençol, roupas, tantas blusas, tantas saias...e eu... Onde que eu vou apanhar dinheiro pra tudo isso? (contando sobre um diálogo com uma amiga). Ai eu disse, mas independente disso eu vou ter que dizer pras irmãs, que eu vou sem enxoval, e eu não tenho dinheiro pra comprar. Ai ela: não tem problema! Eu vou cortar os meus lençóis. Ela pegou dois lençóis de casal, cortou no meio e fez quatro. Então pegou ainda uma toalha de banho e uma outra toalha de banho pequena, cortou e fez duas de rosto. Ai quando a minha irmã viu que eu ia mesmo resolveu também comprar uns tecidos e fizeram saias. ${ }^{12}$

Ingressar na Congregação, portanto, não dependia apenas de encanto e vontade. Como de costume em diferentes congregações e ordens femininas desde o período colonial, em terras brasileiras, e até mesmo antes dele, em solo europeu, um dos requisitos para o ingresso na congregação era o dote. O dote e o enxoval, exigidos tal qual em uma cerimônia de matrimônio. O ingresso na Congregação era também um casamento. Casamento com o maior dos noivos, segundo a tradição religiosa cristã, simbolizado pelo uso de uma aliança a partir da profissão dos votos. A profissão e, portanto, o ingresso na Congregação implicava uma série de compromissos e escolhas. Optar pelo celibato era ingressar em uma nova família. Antes do Vaticano II, até o nome civil era substituído por um nome religioso. A idéia de família era alterada, composta por novas irmãs durante o processo de formação religiosa.

Entende-se por formação religiosa o período em que as características, ou o "jeito de freira”, vão sendo constituídas. Amadeu Cencini, em um curso para formadores, afirma:

\footnotetext{
${ }^{12}$ SILVA. Ir. Eni da. Depoimento. Op.cit.
} 
"Formar, por sua vez, quer dizer ter em mente um modelo preciso, uma forma ou um modo de ser que o sujeito ainda não tem e deve, progressivamente, adquirir, e que constitui sua nova identidade” (CENCINI, 2005, p. 222). Neste sentido, a formação religiosa na Congregação das Irmãzinhas da Imaculada Conceição era (e assim ainda sucede) dividida em fases.

A primeira fase da formação religiosa era o aspirantado. Consta nos diretórios da Congregação que este momento devia ser o "tempo em que, numa atitude de busca, a candidata questiona-se sobre sua vocação à vida consagrada e a Congregação estuda-lhe as aptidões.” $^{13}$ Neste sentido, era dever da irmã responsável pela formação que, atenta, observasse o comportamento da aspirante e a auxiliasse em suas opções em relação à vida religiosa. O desenvolvimento desta fase não contava um tempo específico. Sua duração era determinada pelas aspirações e certezas da candidata e da irmã formadora. Neste momento, a atuação da formadora era direta e fundamental.

Para tanto, ao iniciar o aspirantado, as estudantes recebiam um pequeno livro chamado “Manual da Aspirante”. Este manual tinha por finalidade nortear e acompanhar as questões referentes a esta primeira etapa, a qual, segundo o próprio manual, era um momento de “procura de uma identidade”. Identidade a ser incorporada e assumida ao longo de todo o processo formação. Como geralmente o aspirantado coincidia com os anos de adolescência, fase em que a futura irmã ainda estaria em idade escolar, costumava acontecer nas proximidades dos colégios da Congregação.

As marcas visíveis que caracterizam uma irmã em sua maturidade começam a ser forjadas já nesta primeira etapa. Segundo Grossi, (1989, pág. 31), “o aspirantado é considerado como uma etapa de "experiência”, onde as candidatas a vida religiosa devem tomar contato com o cotidiano do convento e avaliarem se elas estão interessadas ou não em seguir essa carreira”.

Era um momento de transição bastante complexo, afinal representava o relativo abandono da comunidade e família civil para adentrar na Congregação. Porém, ainda não seriam consideradas irmãs de fato. Ainda não haviam passado pelos ritos de consagração. Apenas aspiravam ser.

Entre as perguntas que deveriam ser respondidas ao longo desta fase estavam: “Quem sou? O que quero da vida? Quais são as minhas capacidades? Para que quero consagrar-me ao Senhor nesta congregação?”14.

\footnotetext{
${ }^{13}$ Diretórios da CIIC p. 66.

${ }^{14}$ Manual da Aspirante, usado na década de 1980 por Onice Sansonowicz. Acervo particular de Onice Sansonowicz.
} 
A vocação religiosa aparece aqui como uma semente, que precisa de cuidados. Estes seriam ministrados por meio de: estudo, trabalho, lazer, oração, vida fraterna, engajamento pastoral, reflexões, revisões, encontros, leituras e cursos. Ênfase especial era dada à prática da oração, cuja função declarada era a de fortificar convicções. A oração era prática minuciosamente trabalhada ao longo da formação e tal trabalho era iniciado já no aspirantado. Ao rememorar a importância dada a essa prática, Onice assume certo desconforto:

Levantávamos as 6:30, acho...e rezávamos até as 8:00h (...) Isso era uma tortura para mim, porque elas diziam nos retiros que se a gente não concentrasse, estava abrindo caminho para o demônio, se sentisse sono era a tentação do demônio, mas o sono vinha...era inerente a minha vontade. ${ }^{15}$

Mais que uma prática, a oração era apresentada às formandas como uma verdadeira arte que deveria ser apre(e)ndida e cautelosamente treinada. Através de cursos específicos, com apostilas e exercícios, as meninas eram iniciadas numa prática cujo objetivo único e exclusivo era “descobrir Deus em todas as coisas”16.

A iniciação em tal arte requeria - assim como em qualquer outra, conforme aponta a livreto “A arte de Orar”, utilizado em retiros específicos sobre oração - métodos e disposição. Para se aprender a orar, era necessária uma série de posturas emocionais e até mesmo físicas. Devia-se atentar para a respiração profunda, para o silêncio absoluto e a obstinação. Segundo o livreto, dever-se-ia "rezar mesmo quando não sinto vontade ou não sinto nada. (...) Rezamos com todo nosso ser, daí então a importância da posição do corpo.”

A religião, ainda que seja compreendida enquanto campo simbólico, usa do corpo e exprime-se de modo corporal. Além disso, ele serve para expressar disposições religiosas como a adoração, a penitência, a petição, o perdão, a expiação, manifestadas pelo corpo por meio de olhares, palavras, movimentos e posições perceptíveis na prática da oração (COMBLIN, 2005).

A oração pode ser compreendida como um exercício de introspecção. Um exercício ascético. Requer autodisciplina em relação ao corpo e à mente. Autodisciplina que, quando não atingida, embora atormentasse Onice, fazia parte do ensinamento de que, na vida religiosa, o corpo precisava ser dominado. Tais práticas remetem ao que Michel Foucault chama de “cuidado de si”, o qual implica desde uma prática até a elaboração de um saber norteador da existência. Pode ser caracterizado como um conjunto de ocupações, e não como

\footnotetext{
${ }^{15}$ Sansonowicz. Entrevista.

${ }^{16}$ Livreto “A arte de Orar”. Acervo pessoal de Onice Sansonowicz.
} 
uma atitude geral. É, de fato, uma prática social, pois se configura também na relação com outrem. Consta de uma série de preocupações com o corpo; preocupações estas que dizem respeito a males físicos que podem se comunicar com a alma. O cuidado de si é, dessa forma, resultante de uma série de procedimentos como exercícios de abstinência, exames de consciência, vigília noturna e uma série de práticas que dizem respeito a uma ética de autodomínio.

A prática da oração, com o objetivo de controlar o corpo e os pensamentos de acordo com os pressupostos cristãos, configura uma conduta governada, regulada. A partir do momento em que orar é, conforme apontam os documentos da Congregação, "se abrir a Deus e a própria vida”, esta se insere na temática do governo de si. Para Kleber Prado Filho:

Esta nova forma de experiência do sujeito consigo mesmo abre-se na verdade para os modos cristãos de subjetivação, implicando formas reativas de governo de si mesmo, centradas num ritual de decifração de uma verdade interiorizada, que se desenrola numa relação de sujeição. Trata-se do nascimento da experiência ética cristã(ID., 2006, p. 28)

O governo de condutas e o exercício da autodisciplina pela oração não eram exclusivos do aspirantado. Estavam presentes em todas as etapas do processo formativo e impunham gradativamente às irmãs marcas que lhes permitiriam ser reconhecidas ao longo de toda a vida.

Para atingir tais objetivos, os diretórios recomendam um empenho intensivo em leituras, exames de consciência, meditação, reza do terço, exercícios de penitência, celebrações litúrgicas e, especialmente, participação na missa cotidiana e, se possível, da confissão, uma vez que, segundo os diretórios, estas são práticas que reconfortam o espírito para o exercício da profissão.

No postulantado, segunda fase da formação, eram mantidas e intensificadas as preocupações concernentes à fase anterior. Além disso, esperava-se que nesse momento houvesse um estudo de maior seriedade acerca da vocação religiosa e um aprimoramento da vivência de acordo com os preceitos da Congregação. Era nesta fase também que a formanda iniciava seus estudos bíblico-litúrgico-doutrinários, além de “desenvolver sua feminilidade nos trabalhos manuais, maneira de ser, para assemelhar-se mais a Maria Santíssima”17, conforme diretórios da Congregação. Este modelo era um ideal a ser perseguido pelas irmãzinhas da Imaculada Conceição. Ir. Maria Cristofolini, quando perguntada sobre o objetivo maior de se pertencer à Congregação, afirma que este é o de “ser santo”.

\footnotetext{
${ }^{17}$ Diretórios da CIIC. Op. Cit.
} 
Sobre o conceito de santidade, André Vauchez acusa certo teor de ambiguidade, uma vez que esta, ao mesmo tempo em que implica uma distinção da condição humana, representa também, na relação com o Divino, uma possibilidade de purificação da condição da qual tenta se distanciar. Faz referência a Rudolf Otto, que afirma que a "característica do santo é a de ser ao mesmo tempo diferente e extremamente próximo do homem; todavia, consoante as épocas, evidenciou-se mais ou menos em um outro pólo desta definição” (VAUCHEZ, 1987, p. 287). A partir do Concílio Vaticano II, com a emergência da idéia de "aggiornamento“ também com a teologia da libertação, começaram-se a esboçar novos parâmetros de santidade, segundo os quais a fidelidade à Igreja, a ortodoxia de sua fé e o modelo assumido perante os fiéis passam a ser tão valorizados quanto a exigência da comprovação de milagres. A Teologia da Libertação, de acordo com Mairon Valério (2006), exacerba esses elementos e prevê como fundamento da santidade o amor social e a caridade política. A forma de santidade prevista pela Teologia da Libertação fica bastante explicita as palavras de Leonardo Boff, que transcrevo a seguir:

O santo não é apenas o asceta, o fiel observante das disposições divinas e eclesiásticas, aquele que penetrou e internalizou o mistério sacrossanto de Deus e de sua aparição humana em Jesus Cristo. Tudo isso conserva um valor perene e jamais substituível. Entretanto, nas comunidades de base criou-se a situação para um outro tipo de santidade, aquela do militante. Mais que lutar contra s próprias paixões (é uma luta permanente), luta-se politicamente, contra a expoliação e geração de mecanismos de acumulação excludente e no esforço de construir relações mais comunitárias e equilibradas (BOFF, 1981, p. 194)

Estas características, ainda que a Congregação como corpo institucional não assumisse oficialmente a Teologia da Libertação, existiam e foram, de alguma forma, incorporadas, afinal fazem parte das lembranças de ir. Maria Cristofolini. Ela afirma que a santidade perseguida ao longo da vida religiosa não é a santidade canonizada, mas a fidelidade ao exemplo de Santa Paulina, tendo consciência de que se trata de pessoas reais e concretas lidando com pessoas reais e concretas, com seus problemas e limitações. Claro está que, mesmo com a valorização destes novos predicados e modelos em detrimento de outros, o reconhecimento de características de santidade continua, obviamente, dependente do aval da oficialidade da Igreja Católica.

As características que vão compor esta santidade são as que mais tarde serão professadas na cerimônia dos votos perpétuos. Antes mesmo do rito, que acontecia somente 
no noviciado, terceira fase da formação, os votos já começavam, de alguma forma, a serem experienciados.

A obediência, a castidade e a pobreza são substantivos cotidianos na vida das formandas. Ir. Eni lembra, de forma bastante vívida, as dificuldades existentes nas Casas de Formação no que se referia especialmente à vida comunitária. Esta implicava o exercício das atitudes que, futuramente, conformariam os votos e representariam a entrada efetiva na vida institucionalmente consagrada à religião. Relembra que a adoção da vida comunitária não acontecia sempre de forma festiva. Narra uma passagem dos seus anos de formação, repetindo palavras da irmã formadora:

Olha, eu vou fazer uma reunião e vamos decidir se vocês querem por tudo em comum. Vamos fazer essa experiência. Quem quiser por tudo em comum, se vocês forem de acordo a gente faz. Se quiserem dividir, é...cada uma ficar com o seu, também. Ai logo eu pensei: Meu Deus, se for tudo em comum vai ser ótimo pra mim porque aquilo que eu não tenho com certeza eu vou ter e o pouco que eu tenho eu vou oferecer...em comum. Mas teve aquelas que tinham mais dinheiro e disseram: Nós não queremos. Teve uma que: Eu não quero! Ela tinha muito dinheiro...mas foi só ela que reagiu. É mas, e aquelas que trouxeram menos? Teve umas que trouxeram mais e outras que trouxeram menos... Como é que fica? Ai a irmã disse assim, a Irmã (...): Quem tem muito dá muito, porque vai receber sempre também. E quem tem pouco recebe, mas contribui com pouco, mas pra ela é muito pois é tudo que ela tem. ${ }^{18}$

A vida comunitária, no entanto, não era a única norma que precisaria ser aprendida. Outra, igualmente complexa e que precisava ser incorporada ao longo dos anos, dizia respeito à educação dos sentimentos. A este respeito, ir. Cristofolini elucida que sentimentos existiam porque a vida era comunitária (com o outro), então era preciso educar os sentimentos. Tal educação se passava por meio de retiros e estudos de autoconhecimento e alteridade. Referese, muitas vezes, à autoanálise (por meio da psicanálise), utilizada para descobrir a causa de determinados sentimentos, fossem eles bons ou ruins. Conhece-se o outro a partir do conhecimento de si e isto acontece pelo uso da psicologia, da oração e da razão. ${ }^{19}$ Mais uma vez, o exercício de práticas ascéticas relacionavam-se com questões concernentes ao que conhecemos como cuidado de si. Segundo Foucault (2007, p.72), ao se referir a uma moral sexual:

\footnotetext{
${ }^{18}$ CRISTOFOLINI, Ir. Maria (76 anos). Entrevista. Florianópolis, 31/01/2006. Realizada por Caroline Jaques Cubas. Acervo da autora.

${ }^{19}$ Ir. Maria Cristofolini. Op. Cit.
} 
de abstinência e de domínio que constituem a askesis necessária, o lugar atribuído ao conhecimento de si torna-se mais importante: a tarefa de se por a prova, de se examinar, de controlar-se numa série de exercícios bem definidos, coloca a questão da verdade - da verdade do que se é, do que se faz e do que se é capaz de fazer - no cerne da constituição do sujeito moral.

Tais práticas desempenhavam a função de controlar corpos, uma vez que a sexualidade seria uma profanação do corpo consagrado. Existiam, no entanto, formas de burlar tal controle e essas são narradas por Onice quando afirma que o importante não é sentir algo (referindo-se à sexualidade), mas o que se faz com o sentimento:

Falávamos pouco... Eu lembro que eu fervilhava... (risos). Eu estudava com uma galera do barulho... O negocio era rezar... (risos). Mas entre nos rolava sempre uns papos...Nunca rolou nada... Nem beijo nada, mas eram corpos... Que viviam juntos, que em abraços (tipo com os padres) dissimulavam o que sentiam... A gente vivia um erotismo sem fim... ${ }^{20}$

Podemos aproximar a descrição de Onice às táticas discutidas por Michel de Certeau neste movimento de invenção e reinvenção de um cotidiano. Neste caso, a experiência erótica em um ambiente bastante moralizante figuraria como uma tática, uma linha de escape do controle disciplinar e moralizante, uma vez que esta pode ser compreendida como um "nãolugar (que) lhe permite sem dúvida mobilidade, mas numa docilidade aos azares do tempo, para captar no vôo, as possibilidades oferecidas por um instante”(CERTEAU, 1994, p.100).

A existência de tais táticas não anula, porém, as necessárias certezas em relação à profissão dos votos na última etapa de formação, o noviciado. Esta fase é composta por uma intensificação do que fora antes estudado, além de abarcar também o estudo da pessoa de Jesus Cristo e a vivência de sua mensagem; formação doutrinária e bíblica; documentos da Igreja; curso de catequese com estágios (batismo, crisma, eucaristia); liturgia - mariologia; teologia da vida religiosa; estudo das constituições na formulação original dos fundadores e em seu dinamismo atual; formação humano-social; princípios básicos de saúde; estudo e análise da realidade.

Esta etapa tinha a duração de dois anos e podia ser prorrogada por seis meses. Era a partir deste ponto da formação que acontecia a primeira profissão, a renovação dos votos, a profissão perpétua e a vivência do juniorato, ou seja, um período de experiência comunitária e aprofundamento do que fora visto ao longo da formação, após a profissão dos votos.

\footnotetext{
${ }^{20}$ Onice Sansonowicz. Op. Cit.
} 
Para tanto, existiam critérios bastante específicos nos diretórios da Congregação. São eles: zelo na observância das constituições, do diretório e das normas da Congregação; interesse pela comunidade, província, congregação e Igreja; vivência do espírito da Congregação; integração comunitária; comunicação aberta e franca; aptidão para exercer uma profissão dentro dos setores da Congregação; capacidade de amar e perdoar; respeito consigo e com os outros; coragem - espírito de sacrifício; bom senso; senso crítico; desapego das pessoas, lugares e coisas; co-responsabilidade/ maturidade; libertação de condicionamentos; autodomínio; saúde física e mental; amor ao pobre e ao povo; zelo apostólico e missionário.

A cerimônia de profissão dos votos era bastante simples, precedida de um retiro que durava cerca de oito dias. Era, conforme aponta Bourdieu (1998, p. 167), um rito de instituição que legitimaria a opção daquela que decidira pela vivência institucional da religião perante o corpo de congregadas e o corpo de fiéis, afinal a eficácia deste rito se exerce apenas "na medida em que a pessoa-alvo reconhece quem a exerce como podendo exercê-la de direito”. A partir deste rito, a noviça vai, finalmente, ser reconhecida como irmã. Tal rito representa o compromisso com a Congregação e com Deus, simbolizado pela aliança que passa a utilizar a partir de então.

Em razão de as religiosas fazerem parte do campo religioso, elas também passam a ser portadoras de uma série de bens simbólicos referentes ao seu campo específico. No caso delas, o reconhecimento da posse de tais bens depende de sua passagem por um processo de formação. ${ }^{21}$ Neste processo, composto por fases distintas, nas quais se aprende a ser religiosa, incorporam-se hábitos e costumes. Adquire-se, parafraseando Miriam Pillar Grossi, o “jeito de freira”. Os votos perpétuos (castidade, obediência e pobreza) aconteciam em cerimônia que consagrava, finalmente, a mulher ao estado de religiosa. É o rito de instituição com se reconhecia na religiosa a posse dos bens de salvação.

A autorização a falar em nome da instituição, no entanto, passaria a ser relativizada. A irmã religiosa está vinculada à instituição eclesiástica por seus votos; é reconhecida pelos leigos como religiosa em um processo de distinção. A vida consagrada e seus habitus (compreendido como a naturalização das características e incorporação de regras sociais) específicos vão, de uma forma geral, diferenciar religiosos e leigos. ${ }^{22} \mathrm{~A}$ irmã, porém, não

\footnotetext{
${ }^{21}$ Ao explicar a gênese do campo religioso, Bourdieu recorre a Weber e ressalta distinções entre o lugar do sacerdote, o qual passaria por um processo de formação para falar em nome de uma instituição, e o profeta, que teria a posse dos bens mesmo sem o reconhecimento desse processo e que não estaria ligado à instituição alguma.

${ }^{22}$ Digo de uma forma geral porque esse processo de distinção apresenta algumas complexidades que não serão aqui discutidas mas que merecem ser pontuadas, especialmente após o C.V. II e a tentativa de delimitar novas formas e sentidos para a vida religiosa. Neste sentido cf. CUBAS, Caroline J. Rompendo Hábitos: significados
} 
participa da hierarquia eclesiástica, o que, obviamente, limita suas possibilidades de falar em nome da instituição. Vale lembrar que, mesmo proferindo os votos perpétuos, a irmã não é ordenada como um padre e, portanto, não está apta a ministrar os sacramentos. Não participa de sínodos e das definições mais significativas dentro da Igreja. Seus espaços de atuação, em nome dessa mesma instituição, que restringe sua participação de forma veemente, se limita à atuação pastoral em comunidades de base, escolas, hospitais, etc.

No início do século 20, as mulheres eram impedidas até mesmo de participar em corais. Proibição esta que se estendeu até 1940, quando Pio XII permitiu que as mulheres cantassem, desde que fora do presbitério e da mesa de comunhão. O Código de Direito Canônico, em vigor desde 1983, explicita, no cânon 230, que o ofício de acólito, o ministério litúrgico, pode apenas ser exercido por homens ${ }^{23}$. Ainda no princípio da década de 1980, o papa João Paulo II chegou a vedar a participação das mulheres até mesmo nas funções de ajudantes das missas. Tal decisão foi revogada em 1994. Também em 1994, exatamente em 22 de maio, o mesmo papa ratificou a impossibilidade do sacerdócio feminino, recorrendo, como respaldo argumentativo, a declarações de Paulo VI, em 1975, e à Bíblia. A nãoordenação feminina foi negada em caráter definitivo.

Apesar de negar veementemente a possibilidade de ordenação das mulheres, o papa atribuiu, na carta apostólica Ordinatio Sacerdotalis, fundamental importância ao seu papel na vida e missão da Igreja, outorgando-lhes a responsabilidade pelo "renovamento (sic) e humanização da sociedade, e redescoberta, entre os fiéis, da verdadeira face da Igreja”. ${ }^{24}$ Às mulheres religiosas, irmãs, é reservado o papel de disseminação das verdades da Igreja entre os fiéis. Verdades que deveriam ser aprendidas durante o longo processo de formação. Verdades que as religiosas, ao atuar em meio social, ensinariam pelo trabalho e o exemplo. Verdades em relação às quais elas, as irmãs, não têm poder de definição.

\footnotetext{
do uso do hábito e do seu abandono pelas Irmãzinhas da Imaculada Conceição. Trabalho apresentado no Simpósio Muitas Faces do Cristianismo, promovido pelo Centro de Estudos sobre História da Igreja LatinoAmericana - CEHILA - em agosto de 2005. Disponível em http://www.cehilabrasil.org.br/Biblioteca/Arquivo_102.doc.

${ }^{23}$ Código de Direito Canônico. Disponível em www.vatican.va.

${ }^{24}$ João Paulo II, na carta apostólica Ordinatio Sacerdotalis, de 22 de maio de 1994. Disponível para consulta no endereço eletrônico: $\underline{\text { www.vatican.va }}$
} 


\title{
MEMORIES OF FORMATION: senses and sensibilities during the beginning of religious life in Congregação das Irmãzinhas da Imaculada Conceição (1960 - 1990)
}

\begin{abstract}
The aim of this paper is to study different aspects of female religious training from the perspective of the sensibilities and discipline. For this we present testimony from women who went through the training process in the CIIC. The statements put together with the dialogue and with the training manuals build a rather large scenario, which offers an insight into the construction of meaning and vocations to the later work institutionally linked to the Catholic Church.
\end{abstract}

Keywords: Religious life. Formation. Discipline. Memory.

\section{Referências}

BOFF, Leonardo. Igreja: Carisma e Poder. Petrópolis: Vozes, 1981, p.194.

BOURDIEU, Pierre. Economia das trocas lingüísticas. São Paulo: Edusp, 1998.

CENCINI, Amadeu. Proposta de um itinerário pedagógico do jovem consagrado. Curso para formadores. Roma, 26 a 28 de junho de 1998. In PEREIRA, Willian (org) Análise institucional da vida religiosa consagrada. CRB, Belo Horizonte, 2005.

CERTEAU, Michel de. A invenção do cotidiano. Petrópolis: Vozes, 1994. p. 221-246.

COMBLIN, José. Cristianismo e Corporeidade. Corporeidade e Teologia. São Paulo: Paulinas, 2005.

CUBAS, Caroline J. Rompendo Hábitos: significados do uso do hábito e do seu abandono pelas Irmãzinhas da Imaculada Conceição. Comunicação: Simpósio Muitas Faces do Cristianismo. Centro de Estudos sobre História da Igreja Latino-Americana - CEHILA agosto de 2005. Disponível em http://www.cehila-brasil.org.br/Biblioteca/Arquivo_102.doc.

FILHO, Kleber Prado. Michel Foucault: uma história da governamentalidade. Rio de Janeiro: Achiamé, 2006.

FOUCAULT, Michel. Historia da sexualidade III: o cuidado de si. São Paulo. Ed. Graal. 9a edição, 2007.

. Vigiar e Punir: história das violências nas prisões. Petrópolis: Vozes, 1998. 
GROSSI, Miriam Pillar. Jeito de Freira: estudo antropológico sobre a vocação religiosa feminina. Cadernos de Pesquisa. Fundação Carlos Chagas, n. 73, maio de 1990.

VALÉRIO, Mairon Escorsi. Mártires do Reino: o conceito de santidade na teologia da libertação in Anais do II Simpósio Internacional sobre Religiões, Religiosidades e Culturas. Dourados: UFMS/ UFGD, 2006.

VAUCHEZ, André. Santidade in Enciclopédia Einaudi. Vol.12. Lisboa, Imprensa Nacional Casa da Moeda, 1987. 